\title{
Morphometric Analysis of Piriform Aperture in Human Skulls
}

\author{
Análisis Morfométrico de la Apertura Piriforme en Cráneos Humanos
}

Thales Marx Soares de Araújo ${ }^{1}$; Cristiano Jenes Teixeira da Silva ${ }^{1}$; Luana Karla Nóbrega de Medeiros ${ }^{1}$; Yoshyara da Costa Anacleto Estrela ${ }^{2}$; Nathalie de Almeida Silva ${ }^{3}$; Felippe Barbosa Gomes ${ }^{4}$; Thiago de Oliveira Assis ${ }^{5}$ \& André de Sá Braga Oliveira ${ }^{5}$

DE ARAÚJO, T. M. S.;DA SILVA, C. J. T.; DE MEDEIROS, L. K. N.; ESTRELA, Y. C. A.; SILVA, N. A.; GOMES, F. B.; ASSIS, T. O.\& OLIVEIRA, A. S. B. Morphometric analysis of piriform aperture in human skulls. Int. J. Morphol., 36(2):483-487, 2018.

SUMMARY: The piriform aperture is an anatomical structure generally pear-shaped, formed by some facial bones. The knowledge of its morphological presentation is of significant importance for performing a surgical procedure. This study aimed to analyze the morphometry and shape of the piriform aperture in human skulls, considering the sexual dimorphism of this structure. One hundred (100) human skulls were evaluated. The measurements were made with a digital caliper rule. Two parameters were analyzed: the height of the piriform aperture (R-ANS) - distance between the bottom edge of internasal suture to the anterior nasal spine; width (PA-W) - the longest distance in a transverse plane. Its form was evaluated according to seven types described in the literature and the sex differentiation (based on the Vanrell frame). For data analysis between sexes, we used the Student's t-test ( $<<0.05$; CI: $95 \%$ ). In this study it was observed that the height (R-ANS) of the piriform aperture in males $(31.4 \mathrm{~mm})$ was higher than in females $(29.4 \mathrm{~mm})$, without significant differences. The width (PA-W) had equal means values for both sexes $(25.7 \mathrm{~mm})$. Regarding the shape of the pyriform aperture, it was found that the type I (pear) is the most common in males (43.6\%) and in women the type VII (rounded) is the predominant type (36 \%). When sexes were evaluated in a combined manner, it was observed that the most common was the type I (pear - $39.1 \%$ ) and the less common were type III (diamond - $0.0 \%$ ), type II (inverted heart - $1.6 \%$ ) and type IV (inverted heart - $3.1 \%$ ). Knowledge of these morphometric data and piriform aperture formats is essential for surgical procedures involving this anatomical region. The results, particularly those related to the shape of the piriform aperture in women, may contribute to future work related to this facial structure, leading to better surgical decisions.

KEY WORDS: Piriform; Human skull; Anatomy.

\section{INTRODUCTION}

The piriform aperture is an anatomical structure formed by several bones that are part of the face. It usually has a pear-shape appearance, anatomically formed in its upper portion by the nasal bone, palatal process of the maxilla inferiorly and laterally by the frontal process of the maxilla (Lee et al., 2006; Lee et al., 2008).

The knowledge of the morphometric measures is of relevance for performing a surgical procedure such as rhinoplasty, osteotomies and plastic reconstructions (Citardi et al., 2000). Studies have shown that surgical and traumatic alterations of the piriform aperture may alter the respiratory mechanics (Moreddu et al., 2013). Their form and size may also serve as a basis for anthropological studies of a specific population, related to ethnicity (Homerich et al., 2008).
Considering the assumptions, the study aimed to analyze the morphometry and shape of the piriform aperture of human skulls. From the evaluation of the dimensions and shape of the piriform aperture in human skulls, a better anatomical understanding of this structure can be reached and, in parallel, a better understanding of the clinical implications resulting from pathological alterations, related or not, to the dimorphism presented.

\section{MATERIAL AND METHOD}

The research adopted a quantitative approach. One hundred (100) skulls were used (50 from the FIP anatomy

\footnotetext{
${ }^{1}$ Academics of Physiotherapy. Integrated Colleges of Patos (FIP), Paraíba, Brazil.

${ }^{2}$ Academic of Medicine. Integrated Colleges of Patos (FIP), Paraíba, Brazil.

${ }^{3}$ Academic of Medicine. UNIFACISA, Paraíba, Brazil.

${ }^{4}$ Department of Medicine. UNIFACISA, Paraíba, Brazil.

${ }^{5}$ Department of Morphology. Federal University of Paraíba, Paraíba, Brazil.
} 
laboratory - Patos/PB - and 50 from the UFPE anatomy laboratory - Recife/PE). As an inclusion criterion only skulls in perfect anatomical conditions were selected. Fractured skulls were excluded because they may alter the piriform aperture measurements.

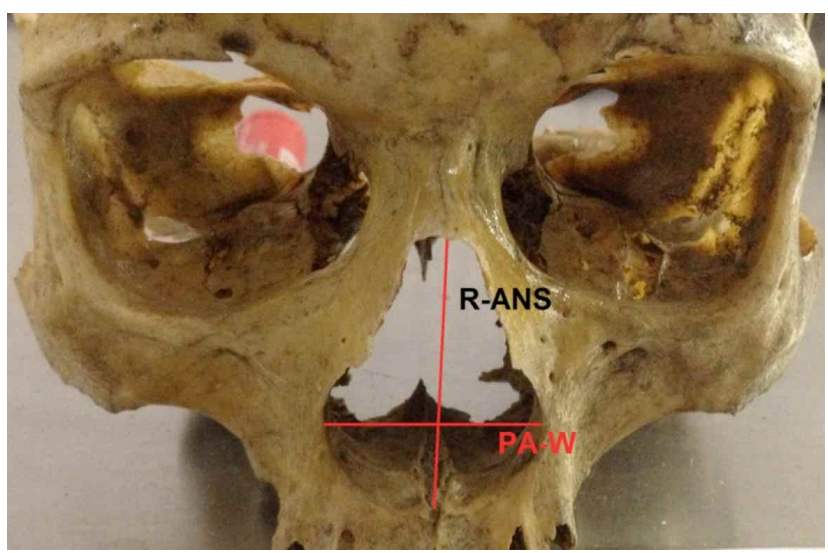

Fig. 1. R-ANS represents the height measurement and PA-W the width (Yüzbasioglu et al., 2014).
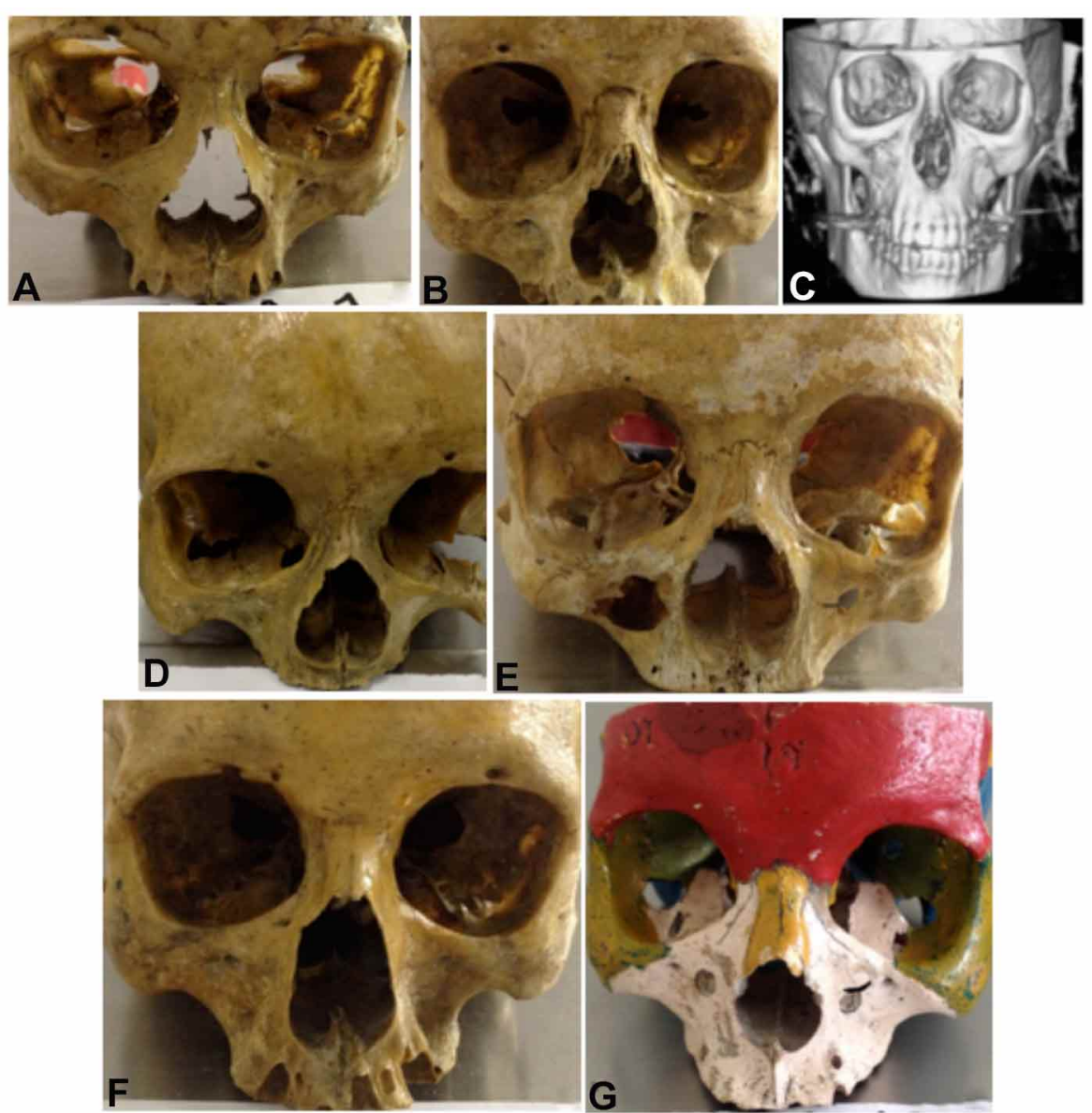

Fig. 2. Pyriform aperture shapes. Type I in the shape of a pear (A), type II inverted heart shape (B), type III diamond shape (D), wide type IV (E), type V oval (F), type VI rectangular and trapezoidal type VII round (G), according to the classification of Yüzbasioglu et al. (2014).
A digital caliper rule (Eccofer@) with a capacity of 150 (one hundred and fifty) millimeters was used for the morphometric analysis. A desktop computer (intel insideTM() was used for data processing. Height, width, and shape of the piriform aperture were described. A Vanrell (Table I) was used to analyze the sexual dimorphism in human skulls (Vanrell, 2002 apud. Lira Júnior et al., 2011).

For analysis of the piriform aperture morphology, the following forms were considered: pear, inverted heart below anterior nasal spine, rhomboid, inverted heart at the anterior nasal spine, oval, trapezoidal and rounded (Fig. 2. A-G) (Yüzbasioglu et al., 2014).

To statistically analyze the data, we used the Student's t-test with a significance level of $95 \%$. The SPSS Desktop version 22.0 (IBM®) program was used for data processing. The results were presented in tables, where the sexes morphometric data were compared and the percentage distribution of the piriform aperture forms of both sexes was presented. The height of the piriform opening (R-ANS), which is the distance between the inferior margin of the internal suture to the anterior nasal spine, and its width $(\mathrm{PA}-\mathrm{W})$, the largest distance in a transverse plane, are presented in $\mathrm{Fi}$ gure 1. The research was approved at the Integrated Colleges of Patos, $\mathrm{Pa}$ tos/PB, Brazil, by the Research Ethics Committee (CAAE $n^{\circ}$ : 48882115.0.0000.5181) according to Resolution $\mathrm{n}^{\circ}$ : 466/2012, also approved by the Research Ethics Committee of Federal University of Pernambuco, Recife/PE, Brazil, as coparticipant institution (CAAE $\mathrm{n}^{\circ}$ : 48882115.0.3001.5208) according to the same Resolution (Brazil, 2013).

\section{RESULTS}

Of the 100 skulls evaluated from both anatomy labs, 64 skulls met the inclusion and exclusion criteria. In this study it was observed that there were no differences between R-ANS and PA-W among the studied genres. Regarding the mean height (R-ANS), males showed a larger size (31.4 mm) than females $(29.4 \mathrm{~mm})$, but without significant differences. When 
combined the genres the mean R-ANS was $(30.6 \mathrm{~mm})$. Regarding the width (PA-W), the female and the male had a mean of $25.7 \mathrm{~mm}$ (Table II).

Regarding the shape of the piriform opening, the type I (pear) was the most common in males $(43.6 \%)$ and type VII (rounded) was the predominant one $(36.0 \%)$ in women. When the sexes were evaluated in a combined manner, it was observed that the most common type was type I $(39.1 \%)$. The less common forms were type III (rhombus - no skulls with this format), type II (inverted heart below the level of the anterior nasal spine - $1.6 \%$ ), and type IV (heart inverted at the level of the anterior nasal spine $3.1 \%$ ) (Table III). The description and format of pyriform aperture types can be seen in Figures 2 A-G. (Yüzbasioglu et al., 2014).

Table I. Differentiation of sexual dimorphism in human skulls.

\begin{tabular}{lll}
\hline Feature & Female Skull & Mel Skull \\
\hline Front & More vertical. & More backwards inclined. \\
Glabella & Not protruding; continuation of the frontal-nasal & Glabella and protruding superciliary arches. \\
profile. & Curve. & Inclined. \\
Frontal-nasal joint & Cutting. & Rhombus. \\
Supraorbital margins & Less developed, when the skull is placed on a plane & Prominent, serving as support points \\
Mastoid process & surface, it rests on the maxilla and the occipital & making the skull more stable when placec \\
& bones, with less stability. & on a plane surface. \\
Weight & Lighter skull . & Heavier skull. \\
Occipital condyles & Short and wide. & Long and narrow. \\
Mastoid and styloid processes & Smaller. & Larger
\end{tabular}

Table II. Mean and SD values of the piriform aperture parameters of both sexes. N=64. Source: Anatomy Laboratories - Department of Morphological Sciences (FIP and UFPE).

\begin{tabular}{|c|c|c|c|c|c|c|c|}
\hline Parameters & $\begin{array}{l}\text { MALE } \\
\text { Min-Max }\end{array}$ & Mean (SD) & $\begin{array}{l}\text { FEMALE } \\
\text { Min-Max }\end{array}$ & Mean (SD) & $\begin{array}{l}\text { COMBINED } \\
\text { Min-Max }\end{array}$ & Mean (SD) & $p$ \\
\hline R-ANS (mm) & $25.0-35.8$ & $31.4(3.3)$ & $23.2-32.8$ & $29.4(3.9)$ & $23.2-35.8$ & $30.6(3.6)$ & 0.31 \\
\hline PA-W (mm) & $22.5-31.0$ & $25.7(1.9)$ & $20.2-30.5$ & $25.7(2.5)$ & $20.2-31.0$ & $25.7(2.2)$ & 0.97 \\
\hline
\end{tabular}

R-ANS: Height measurement; PA-W: Width measurement; N: number; Min: Minimum*; Max: Maximum*; SD: standard deviation; p: level of significance.

Table III. Piriform aperture types percentage. Source: Anatomy Laboratories - Department of Morphological Sciences (FIP and UFPE).Source: Anatomy Laboratories - Department of Morphological Sciences (FIP and UFPE).

\begin{tabular}{|c|c|c|c|c|c|c|c|c|}
\hline \multirow[b]{2}{*}{ SEX } & \multicolumn{8}{|c|}{ TYPES } \\
\hline & $\begin{array}{l}\text { Type I } \\
\text { n (\%) }\end{array}$ & $\begin{array}{c}\text { Type II } \\
\text { n (\%) }\end{array}$ & $\begin{array}{r}\text { Type III } \\
\text { n (\%) }\end{array}$ & $\begin{array}{r}\text { Type IV } \\
\text { n (\%) }\end{array}$ & $\begin{array}{r}\text { Type V } \\
\text { n (\%) }\end{array}$ & $\begin{array}{c}\text { Type VI } \\
\text { n (\%) }\end{array}$ & $\begin{array}{c}\text { Type VII } \\
\text { n (\%) }\end{array}$ & $\begin{array}{l}\text { Total } \\
\mathrm{n}(\%)\end{array}$ \\
\hline Male & $\begin{array}{c}17 \\
(43.6)\end{array}$ & - & - & $\begin{array}{c}1 \\
(2.6)\end{array}$ & $\begin{array}{c}7 \\
(17.9)\end{array}$ & $\begin{array}{c}2 \\
(5.1)\end{array}$ & $\begin{array}{c}12 \\
(30.8)\end{array}$ & $\begin{array}{c}39 \\
(60.9)\end{array}$ \\
\hline Female & $\begin{array}{c}8 \\
(32.0)\end{array}$ & $\begin{array}{c}1 \\
(4.0)\end{array}$ & - & $\begin{array}{c}1 \\
(4.0)\end{array}$ & $\begin{array}{c}5 \\
(20.0)\end{array}$ & $\begin{array}{c}1 \\
(4.0)\end{array}$ & $\begin{array}{c}9 \\
(36.0)\end{array}$ & $\begin{array}{c}25 \\
(39.1)\end{array}$ \\
\hline Combined & $\begin{array}{c}25 \\
(39.1)\end{array}$ & $\begin{array}{c}1 \\
(1.6)\end{array}$ & - & $\begin{array}{c}2 \\
(3.1)\end{array}$ & $\begin{array}{c}12 \\
(18.7)\end{array}$ & $\begin{array}{c}3 \\
(4.7)\end{array}$ & $\begin{array}{c}21 \\
(32.8)\end{array}$ & $\begin{array}{c}64 \\
(100)\end{array}$ \\
\hline
\end{tabular}

Type I: pear shape; Type II: inverted heart shape below the level of the anterior nasal spine; Type III: diamond shape; Type IV: inverted heart shape at the level of the anterior nasal spine; Type V: oval shape; Type VI: trapezoidal shape; Type VII: round shape.

\section{DISCUSSION}

This study was performed with cadaveric skulls and a digital caliper rule. This choice yielded some advantages. i.e.: to accurately classify the male and female sexes; the ability to increase the sample number; do not subject 
individuals to radiation as in other studies (Prado et al., 2011; Yüzbasioglu et al., 2014).

The analysis of the obtained data from the piriform aperture is very important for the plastic surgery, pulmonology, buco-maxillofacial surgeries and otolaryngologists areas. It can decide the most effective procedure, for example: osteotomies (Prokop, 2000; Karadag et al., 2011).

Studies have suggested that the width and shape of the piriform aperture are extremely important when it comes to good-quality nasal breathing (Prokop, 2000; Lee $e t$ $a l ., 2006)$. It is also known that the moistening and heating of the inspired air are better with a narrow piriform aperture, and the shape of this structure is a relevant factor for climate adaptations (Hawang et al., 2005).

In our results, the R-ANS was higher than the Germans' and Koreans' papers (Lang \& Baumeister, 1982, obtained from the study by Hwang et al.,; Lee et al., 2008), but lower than the Turks (Table IV) (Yüzbasioglu et al.,). The width (PA-W) was wider than the Turks (Table IV) (Yüzbasioglu et al.,), Korean, Caucasian, German, Austrian, Anatolian and American results, and smaller than in black people (Table IV) (Lang \& Baumeister, 1982, obtained from the study by Hwang et al.; Hoffman et al., 1991; Ofidile, 1994; Hommerich \& Riegel, 2002; Karadag et al., 2011).

The width of the piriform aperture increases twice in size, starting from infancy to adulthood, continuing its development even after the age of twenty (Cantín López et al., 2009). In many studies, height (R-ANS) and width (PA$\mathrm{W}$ ) is higher in men than in women (Table IV) (Hommerich \& Riegel, Erdem et al., 2004; Lee et al., 2008; Cantín López et al.). The width (PA-W) of the Korean population is narrower in women (Table IV) (Hwang et al.). It was analyzed that in the black people the width (PA-W) is wider than in whites (Table IV) (Hoffman et al.). In our evaluation it was observed that the males mean height (R-ANS) was higher, but without significant differences, and the width (PA-W) shows equal results for both sexes (Table IV).

Regarding the shape of this facial structure, it was observed that the predominant format in African and African American individuals was oval, and triangular in the American, Indian and Austrian population (Ofidile). In Turkey the pear form was also observed for both sexes (Yüzbasioglu et al.). In our study the most present form was the pear in men and rounded in women. This last result differs from all previous studies, showing that in Brazilian Northeast this form is the most evident in female human skulls.

In view of these data, a new form of piriform aperture presentation was known in women. This finding leads to a greater knowledge of this anatomical structure, related to the sex of the individual, which may be of great relevance in the surgical decision involving this facial area.

\section{CONCLUSION}

The study concluded that, for a population from northeastern Brazil, the mean height (R-ANS) of the piriform aperture was higher in the male sex compared to the female, but without significant differences. The width (PA-W) shows an equal average for both sexes. A high percentage of the masculine pear type and female rounded type were also observed. When we combined both sexes it was observed that the pear-shape type was predominant. The results obtained in this study showed the importance of the morphological knowledge of the piriform aperture. The unusual shape found in women in our study may contribute

Table IV. Means of piriform aperture comparison.

\begin{tabular}{|c|c|c|c|c|c|c|c|}
\hline \multirow[b]{2}{*}{ Studies } & \multirow[b]{2}{*}{ Population } & \multicolumn{3}{|c|}{ Height } & \multicolumn{3}{|l|}{ Width } \\
\hline & & M & $\mathrm{F}$ & Total & M & $\mathrm{F}$ & Total \\
\hline Our study & Brazilian & 31.4 & 29.4 & 30.4 & 25.7 & 25.7 & 25.7 \\
\hline Hwang et al. (2005) & Korean & 30.1 & 28 & 29 & 25.7 & 25.4 & 25.5 \\
\hline Lee et al. (2008) & Korean & - & - & - & 24.34 & 22.82 & 23.5 \\
\hline Yüzba et al. (2014) & Turk & 33.4 & 30.1 & 31.7 & 24.6 & 23.3 & 23.9 \\
\hline Lang \& Baumeister (1982) (Apud Hwang et al., 2005) & German & - & - & 29.1 & - & - & 23.6 \\
\hline Hommerich \& Riegel (2002) & German & - & - & - & 23.6 & 22.6 & 23.1 \\
\hline \multirow[t]{2}{*}{ Hoffman et al. (1991) } & White A & - & - & - & - & - & 23.7 \\
\hline & Black A & - & - & - & - & - & 26.7 \\
\hline Karada et al. (2011) & Anatolia & - & - & - & 18.83 & 18.19 & 18.5 \\
\hline \multirow[t]{2}{*}{ Ofodile (1994) } & Austrians & - & - & - & - & - & 21.6 \\
\hline & Americans & - & - & - & - & - & 23.4 \\
\hline
\end{tabular}

Source: Yüzbasioglu et al. (2014). M: male; F: female; A: Americans. 
as a reference for future studies related to the area and in the surgical area. Besides it may lead to valuable information to help in a better surgical decision involving osteotomies and plastic reconstructions.

DE ARAÚJO, T. M. S.;DA SILVA, C. J. T.; DE MEDEIROS, L. K. N.; ESTRELA, Y. C. A.; SILVA, N. A.; GOMES, F. B.; ASSIS, T. O.\& OLIVEIRA, A. S. B. Análisis morfométrico de la apertura piriforme en cráneos humanos. Int. J. Morphol., 36(2): 483-487, 2018.

RESUMEN: La apertura piriforme es una estructura anatómica generalmente en forma de pera, formada por algunos huesos faciales. El conocimiento de su presentación morfológica es de importancia en los procedimientos quirúrgicos. Este estudio tuvo como objetivo analizar la morfometría y la forma de la apertura piriforme en cráneos humanos, teniendo en cuenta el dimorfismo sexual de esta estructura. Se evaluaron cien cráneos humanos y las mediciones se realizaron con una regla de pinza digital. Se analizaron dos parámetros: la altura de la apertura piriforme - distancia entre el margen inferior de la sutura internasal y la espina nasal anterior; ancho de la distancia mayor en un plano transversal. Su forma fue evaluada según siete tipos descritos en la literatura y la diferenciación de sexo (basada en el marco de Vanrell). Para el análisis de datos entre los sexos, se utilizó la prueba t de Student ( $\mathrm{p}$ $<0,05$; IC: $95 \%$ ). En este estudio se observó que la altura (R-ANS) de la apertura piriforme en los hombres $(31,4 \mathrm{~mm})$ era más alta que en las mujeres $(29,4 \mathrm{~mm})$, sin diferencias significativas. El ancho (PA-A) tenía valores medios iguales para ambos sexos $(25,7$ $\mathrm{mm})$. En cuanto a la forma de la apertura piriforme, se encontró que el tipo I (pera) es el más común en los hombres $(43,6 \%)$ y en las mujeres el tipo VII (redondeado) es el tipo predominante (36 $\%$ ). Cuando se evaluaron los sexos en conjunto, se observó que el más común fue el tipo I (pera - 39,1\%) y los menos comunes fueron el tipo III (diamante - 0,0 \%), tipo II (corazón invertido bajo la espina nasal 1,6\%) y tipo IV (corazón invertido a nivel de la espina nasal- 3,1\%). El conocimiento de estos datos morfométricos y formatos de apertura piriforme es esencial para los procedimientos quirúrgicos que involucran esta región anatómica. Los resultados, en particular los relacionados con la forma de la apertura piriforme en las mujeres, pueden contribuir al trabajo futuro relacionado con esta estructura facial, lo que llevará a mejores decisiones quirúrgicas.

PALABRAS CLAVE: Apertura piriforme; Cráneo humano; Anatomía.

\section{REFERENCES}

Cantin López, M.; Suazo Galdames, I. C.; Zavando Matamala, D. A. \& Smith, R. L. Sexual dimorphism determination by piriform aperture morphometric analysis in Brazilian human skulls. Int. J. Morphol., 27(2):327-31, 2009.

Citardi, M. J.; Hardeman, S.; Hollenbeak, C. \& Kokoska, M. Computeraided assessment of bony nasal pyramid dimensions. Arch. Otolaryngol.
Head Neck Surg., 126(8):979-84, 2000.

Erdem, T.; Ozturan, O.; Erdem, G.; Akarcay, M. \& Miman, M. C. Nasal pyriform aperture stenosis in adults. Am. J. Rhinol., 18(1):57-62, 2004.

Hoffman, B. E.; McConathy, D. A.; Coward, M. \& Saddler, L. Relationship between the piriform aperture and interalar nasal widths in adult males. J. Forensic Sci., 36(4):1152-61, 1991.

Hommerich, C. P. \& Riegel, A. Measuring of the piriform aperture in humans with 3D-SSD-CT-reconstructions. Ann. Anat., 184(5):455-9, 2002.

Hwang, T. S.; Song, J.; Yoon, H.; Cho, B. P. \& Kang, H. S. Morphometry of the nasal bones and piriform apertures in Koreans. Ann. Anat., 187(4):411-4, 2005.

Karadag, D.; Ozdol, N. C.; Beriat, K. \& Akinci, T. CT evaluation of the bony nasal pyramid dimensions in Anatolian people. Dentomaxillofac. Radiol., 40(3):160-4, 2011

Lee, J. C.; Yang, C. C.; Lee, K. S. \& Chen, Y. C. The measurement of congenital nasal pyriform aperture stenosis in infant. Int. J. Pediatr. Otorhinolaryngol., 70(7):1263-7, 2006.

Lee, S. H.; Yang, T. Y.; Han, G. S.; Kim, Y. H. \& Jang, T. Y. Analysis of the nasal bone and nasal pyramid by three-dimensional computed tomography. Eur. Arch. Otorhinolaryngol., 265(4):421-4, 2008.

Lira Júnior, R.; Lima, D. M. B.; Ferreira, A. C. A.; Sousa, E. M. D. \& Lucena, L. B. S. Avaliação topográfica do forame infraorbital em crânios secos humanos. Pesqui. Bras. Odontopediatr. Clin. Integr., 11(4):497500, 2011.

Ministério da Saúde. Conselho Nacional de Saúde (CONEP). Resolução $n^{\circ}$ 466/2012, Publicada em 13 de Julho de 2013 sobre Pesquisa Envolvendo Seres Humanos. Brasília, Ministério da Saúde, Conselho Nacional de Saúde (CONEP), Brasil, 2013.

Moreddu, E.; Puymerail, L.; Michel, J.; Achache, M.; Dessi, P. \& Adalian, P. Morphometric measurements and sexual dimorphism of the piriform aperture in adults. Surg. Radiol. Anat., 35(10):917-24, 2013.

Ofodile, F. A. Nasal bones and pyriform apertures in blacks. Ann. Plast. Surg., 32(1):21-6, 1994.

Prado, F. B.; Caldas, R. A.; Rossi, A. C.; Freire, A. R.; Groppo, F. C.; Caria, P. H. F. \& Júnior, E. D. Piriform aperture morphometry and nasal bones morphology in Brazilian population by postero-anterior caldwell radiographys. Int. J. Morphol., 29(2):393-8, 2011.

Prokop, M. Multislice CT angiography. Eur. J. Radiol., 36(2):86-96, 2000.

Yüzbasioglu, N.; Yilmaz, M. T.; Çicekcibasi, A. E.; Seker, M. \& Sakarya, M. E. The evaluation of morphometry of nasal bone and pyriform aperture using multidetector computed tomography. J. Craniofac. Surg., 25(6):2214-9, 2014.

Corresponding author:

André de Sá Braga Oliveira

Universidade Federal da Paraíba

Cidade Universitária

Castelo Branco

João Pessoa, PB

Zip Code: 58051-900

BRAZIL

Email: andre.sboliveira@gmail.com

Received: 14-11-2017

Accepted: 30-01-2018 